\title{
CB1 receptor mediates the effects of glucocorticoids on AMPK activity in the hypothalamus
}

\author{
Miski Scerif', Tamás Füzesi ${ }^{2}$, Julia D Thomas', Blerina Kola', Ashley B Grossman ${ }^{1,4}$, \\ Csaba Fekete ${ }^{2,3}$ and Márta Korbonits ${ }^{1}$ \\ ${ }^{1}$ Centre for Endocrinology, William Harvey Research Institute, Barts and the London School of Medicine and \\ Dentistry, Queen Mary University of London, London EC1M 6BQ, UK \\ ${ }^{2}$ Department of Endocrine Neurobiology, Institute of Experimental Medicine, Hungarian Academy of Sciences, \\ Budapest 1083, Hungary \\ ${ }^{3}$ Division of Endocrinology, Diabetes, Metabolism and Molecular Medicine, Department of Medicine, Tupper \\ Research Institute, Tufts Medical Center, Boston, Massachusetts 02111, USA \\ ${ }^{4}$ Oxford Centre for Diabetes, Endocrinology and Metabolism, University of Oxford, Oxford, UK
}

\author{
Correspondence \\ should be addressed \\ to M Korbonits \\ Email \\ m.korbonits@qmul.ac.uk
}

\begin{abstract}
AMP-activated protein kinase (AMPK), a regulator of cellular and systemic energy homeostasis, can be influenced by several hormones. Tissue-specific alteration of AMPK activity by glucocorticoids may explain the increase in appetite, the accumulation of lipids in adipose tissues, and the detrimental cardiac effects of Cushing's syndrome. Endocannabinoids are known to mediate the effects of various hormones and to influence AMPK activity. Cannabinoids have central orexigenic and direct peripheral metabolic effects via the cannabinoid receptor type 1 (CB1). In our preliminary experiments, WT mice received implants of a corticosterone-containing pellet to establish a mouse model of Cushing's syndrome. Subsequently, WT and Cb1 (Cnr1)-knockout (CB1-KO) littermates were treated with corticosterone and AMPK activity in the hypothalamus, various adipose tissues, liver and cardiac tissue was measured. Corticosterone-treated CB1-KO mice showed a lack of weight gain and of increase in hypothalamic and hepatic AMPK activity. In adipose tissues, baseline AMPK activity was higher in CB1-KO mice, but a glucocorticoid-induced drop was observed, similar to that observed in WT mice. Cardiac AMPK levels were reduced in CB1-KO mice, but while WT mice showed significantly reduced AMPK activity following glucocorticoid treatment, CB1-KO mice showed a paradoxical increase. Our findings indicate the importance of the CB1 receptor in the central orexigenic effect of glucocorticoid-induced activation of hypothalamic AMPK activity. In the periphery adipose tissues, changes may occur independently of the CB1 receptor, but the receptor appears to alter the responsiveness of the liver and myocardial tissues to glucocorticoids. In conclusion, our data suggest that an intact cannabinoid pathway is required for the full metabolic effects of chronic glucocorticoid excess.
\end{abstract}

\section{Key Words}

- glucocorticoids

- CB1 receptor

- AMPK activity
Journal of Endocrinology (2013) 219, 79-88 http://joe.endocrinology-journals.org DOI: 10.1530/JOE-13-0192
() 2013 Society for Endocrinology Printed in Great Britain
Published by Bioscientifica Ltd 


\section{Introduction}

Cushing's syndrome results from chronic exposure to high doses of glucocorticoids. Endogenous Cushing's syndrome is rare and may be caused by an adrenocorticotrophin (ACTH)secreting pituitary adenoma (Cushing's disease) or a cortisolsecreting adrenal tumour or, more rarely, by ectopic ACTH or corticotrophin-releasing hormone $(\mathrm{CRH})$ production. On the other hand, exogenous (iatrogenic) Cushing's syndrome affects more than half a million people in the UK as a result of long-term glucocorticoid treatments (van Staa et al. 2000). Glucocorticoids lead to glucose mobilisation, fat redistribution and protein catabolism. These effects are exaggerated in Cushing's syndrome. Some of the complications of Cushing's syndrome include central obesity, impaired glucose tolerance, insulin resistance, dyslipidaemia, hepatic steatosis and systemic arterial hypertension, a state similar to the metabolic syndrome (Pivonello et al. 2005). Cardiac abnormalities, such as left ventricular hypertrophy, atherosclerosis and myocardial ischaemia, cannot be fully explained as resulting from insulin resistance or hypertension and hence suggestions of an additional direct effect of cortisol excess on the myocardium have been emerging (Muiesan et al. 2003). Adverse effects on muscle (myopathy), bone (osteoporosis), mood and cognitive function also occur. These manifestations lead to increased cardiovascular risk, impaired quality of life and reduced life expectancy (Pivonello et al. 2005).

Many of the changes observed during glucocorticoid excess correspond to the metabolic steps regulated by AMPactivated protein kinase (AMPK). AMPK is a regulator of cellular and systemic energy homeostasis and acts as a sensor of energy status. AMPK may be activated through physiological and pathological mechanisms (Kahn et al. 2005). The inhibition of ATP synthesis by pathological processes such as glucose deprivation, ischaemia, hypoxia, heat shock, metabolic poisons and oxidative stresses leads to AMPK activation. Physiologically, muscle contraction accelerates ATP consumption, thus activating AMPK. Once activated, AMPK switches off anabolic pathways, such as fatty acid, triglyceride and cholesterol synthesis, in favour of catabolic pathways, such as glycolysis and fatty acid oxidation. With the aim of restoring energy balance, ATP production is increased and energy-utilising pathways are inhibited. AMPK has acute effects through the direct phosphorylation of target enzymes and long-term effects through the regulation of gene and protein expression (Kola et al. 2006).

The activation of hypothalamic AMPK leads to an increase in appetite and that of myocardial AMPK is protective in myocardial ischaemia (Kola et al. 2006).
The activation of AMPK leads to reduced adipose tissue lipid stores with inhibition of lipogenesis and also to reduced lipolysis with reduction in free fatty acid release. Interestingly, AMPK activity is lower in the adipose tissues of patients who are insulin-resistant than in those of BMImatched insulin-sensitive subjects (Gauthier et al. 2011), and in individuals treated with metformin, AMPK activation has been demonstrated (Boyle et al. 2011). The activation of AMPK in the liver leads to the inhibition of gluconeogenesis and fatty acid and cholesterol synthesis. AMPK mediates the action of several metabolic hormones. These hormones include leptin, adiponectin, insulin and ghrelin (Kola et al. 2006). We have shown previously that glucocorticoids have tissue-dependent regulatory effects on AMPK activity (Christ-Crain et al. 2008, Kola et al. 2008). AMPK has also been implicated in the mediation of the metabolic effects of cannabinoids (Kola et al. 2005).

Cannabinoids have central and peripheral metabolic effects via the cannabinoid receptor type 1 (CB1), which is widely expressed in the hypothalamus (Wittmann et al. 2007), but also found in peripheral tissues including adipose tissues, liver and the myocardium (Butler \& Korbonits 2009). The activation of central hypothalamic CB1 receptors is associated with appetite stimulation (Cota et al. 2003). Cannabinoids have been reported to have cardioprotective roles in myocardial ischaemia (Underdown et al. 2005), and cannabinoid actions on the cardiovascular system have been widely interpreted as being mediated by CB1 receptors, although some of the reported cardiovascular effects of cannabinoids are mediated by non-CB1 receptors (Hiley 2009). In adipose tissues and liver, CB1 receptor activation promotes fat accumulation (Cota et al. 2003, Osei-Hyiaman et al. 2005, 2008).

It appears that the cannabinoid-CB1 system interacts with a number of hormonal systems and can mediate their effects (Di Marzo et al. 2001, Kola et al. 2008, Butler \& Korbonits 2009, Turu et al. 2009). Glucocorticoids stimulate endocannabinoids in the hypothalamus (Di et al. 2003, 2005). We have shown previously glucocorticoidinduced changes in hypothalamic AMPK to be associated with increased hypothalamic endocannabinoid content (Christ-Crain et al. 2008). This suggests that the endogenous cannabinoid system may be required for the effects of glucocorticoids on hypothalamic AMPK activity and ultimately appetite. While glucocorticoids and cannabinoids have opposing effects on AMPK activity in the liver and myocardium, we have shown previously that both glucocorticoids and cannabinoids stimulate AMPK activity

Published by Bioscientifica Ltd 
in the hypothalamus and inhibit it in adipose tissues (Kola et al. 2005, 2008, Christ-Crain et al. 2008). In the present study, we established a mouse model of Cushing's syndrome and we further investigated the role of the CB1 receptor in the tissue-specific effects of glucocorticoids on AMPK activity by utilising Cb1 (Cnr1)-knockout (CB1-KO) mice.

\section{Materials and methods}

\section{Animals}

CB1-KO mice were generated at the Université Libre de Bruxelles (Ledent et al. 1999) and bred at the Institute of Experimental Medicine, Hungarian Academy of Sciences (Budapest). Adult male WT and CB1-KO mice were housed under standard environmental conditions (light between 0600 and $1800 \mathrm{~h}$, temperature $22 \pm 1{ }^{\circ} \mathrm{C}$, and rodent chow and water provided with the animals allowed to feed and drink ad libitum). All experimental protocols were reviewed and approved by the local Animal Welfare Committee.

Initial experiments to establish a mouse model of Cushing's syndrome using WT mice indicated that the $40 \mathrm{mg} /$ mouse corticosterone dose, equivalent in terms of milligram corticosterone/body weight in the previously established rat model (Bell et al. 2000, Dallman et al. 2003) and used by us (Christ-Crain et al. 2008), was excessively high, leading to cachexia and fatal diabetes. With the aim of finding an adequate corticosterone dose to induce Cushing's syndrome, preliminary experiments were carried out in WT mice treated with a surgically implanted s.c. pellet containing $40 \mathrm{mg}$ cholesterol (placebo control) or a $40 \mathrm{mg}$ pellet containing a mixture of cholesterol and corticosterone (corticosterone content 5, 10 or $20 \mathrm{mg}$; $n=5$ for each group). The pellets containing varying amounts of corticosterone were prepared using commercially available moulds, as described previously (Bell et al. 2000 ). Animals were provided with a bottle of $0.5 \% \mathrm{NaCl}$ and a second bottle containing 30\% sucrose and allowed to drink ad libitum. Body weight and calorie (chow and sucrose) intake were recorded daily. Mice were killed 2 weeks after the insertion of pellets. Plasma samples were collected in the morning during killing and assayed for corticosterone, ACTH (Zelena et al. 2011) and glucose. The preliminary experiments revealed that $5 \mathrm{mg}$ corticosterone was sufficient to induce Cushing's syndrome. Therefore, WT and CB1-KO littermates were treated with a surgically implanted s.c. pellet containing $40 \mathrm{mg}$ cholesterol (placebo control) or $35 \mathrm{mg}$ cholesterol $+5 \mathrm{mg}$ corticosterone ( $n=5-6$ for each group). Tissues (hypothalamus, visceral (mesenteric, perirenal and epididymal) and subcutaneous (inguinal) adipose tissues, liver and heart) were frozen on dry ice and stored at $-80^{\circ} \mathrm{C}$.

\section{Measurement of AMPK activity}

The kinase assays for determining AMPK activity have been described previously (Hawley et al. 2003, Kola et al. 2005). Briefly, tissues were weighed and homogenised with a Precellys 24 machine using CK14 tubes containing ceramic beads (Stretton Scientific, Stretton, UK) at 6500 r.p.m. for three cycles of $20 \mathrm{~s}$ in a lysis buffer containing $50 \mathrm{mM}$ Tris- $\mathrm{HCl}, 50 \mathrm{mM} \mathrm{NaF}, 5 \mathrm{mM} \mathrm{Na}$ pyrophosphate, $1 \mathrm{mM}$ EDTA, $10 \%$ (v/v) glycerol, $1 \%$ Triton X-100, $1 \mathrm{mM}$ dithiothreitol, $1 \mathrm{mM}$ benzamidine, $0.1 \mathrm{mM}$ PMSF and $5 \mu \mathrm{g} / \mathrm{ml}$ soybean trypsin inhibitor. Tissue protein content was determined using the BCA assay (Pierce, Rockford, IL, USA). AMPK was immunoprecipitated with an equal mixture of $\alpha 1 \mathrm{AMPK}$ and a2AMPK antibodies, and AMPK activity was determined by the entity of ${ }^{32} \mathrm{P}$-incorporation into SAMS (amino acid sequence: HMRSAMSGLHLVKRR) (Pepceuticals Ltd., Nottingham, UK), a synthetic peptide substrate of AMPK.

\section{Statistical analysis}

Statistical analysis of data was performed on StatsDirect (Ian Buchan, Cambridge, UK). Data were analysed using the Kruskal-Wallis test followed by the Conover-Inman test for multiple group comparisons. Data are expressed as means \pm s.E.M.s, $n=5-6$ in each treatment group. To allow for comparison between experiments performed on different days and comparison between groups of different genetic backgrounds, AMPK assay results are presented as the percentage of controls, where control refers to WT mice treated with corticosterone (placebo) pellets. A $P$ value $<0.05$ was considered significant.

\section{Results}

\section{Mouse model of Cushing's syndrome}

Hormonal parameters confirmed that glucocorticoidtreated WT mice had the expected profile of Cushing's syndrome. WT mice treated with 5,10 and $20 \mathrm{mg}$ corticosterone showed significantly increased plasma corticosterone levels $(P=0.0006, P<0.0001$ and $P<0.001$ respectively; Fig. 1A). Conversely, plasma ACTH levels were decreased with corticosterone treatment as expected (Fig. 1B). WT mice treated with low-dose $(5 \mathrm{mg})$ corticosterone displayed significant weight gain $(P=0.0356$ vs WT

Published by Bioscientifica Ltd. 
A

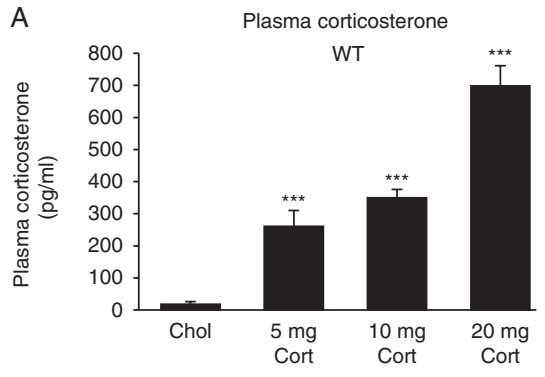

D

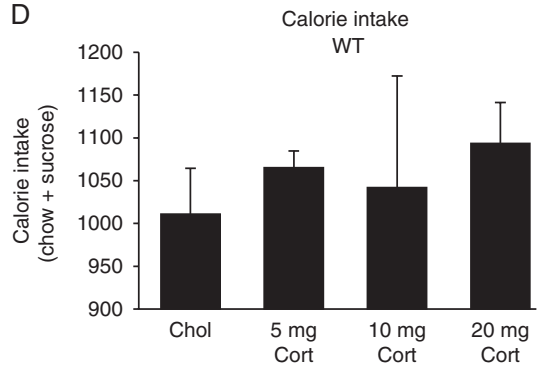

B

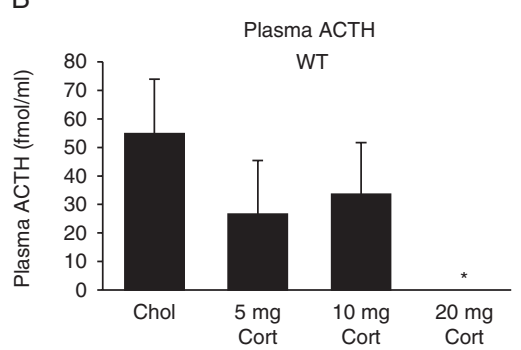

E

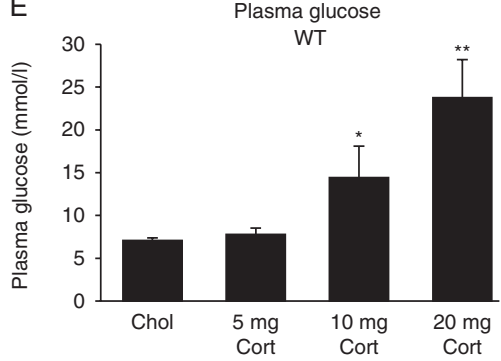

C
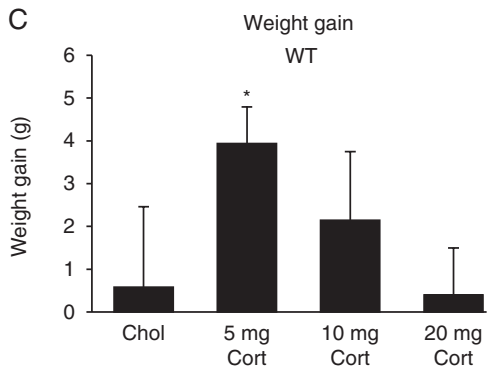

$\mathrm{F}$

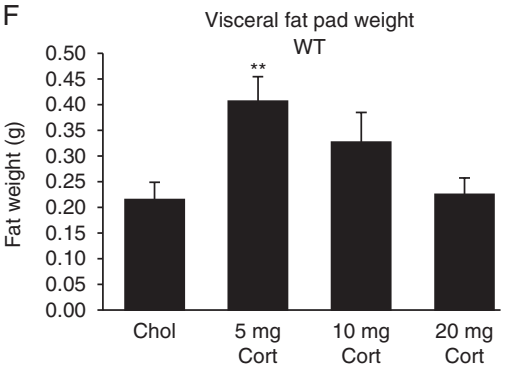

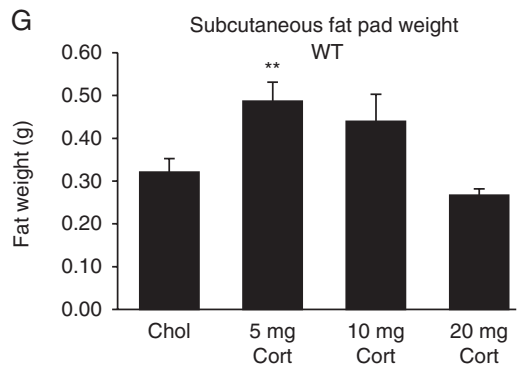

Figure 1

(A) Effect of glucocorticoid treatment on plasma corticosterone levels in WT mice. (B) Effect of glucocorticoid treatment on plasma ACTH levels in WT mice. (C) Effect of glucocorticoid treatment on weight gain in WT mice. (D) Effect of glucocorticoid treatment on calorie intake in WT mice.

(E) Effect of glucocorticoid treatment on plasma glucose levels in WT mice.

control), while the other two groups were not significantly different from the control mice (Fig. 1C). Corticosteronetreated WT mice showed a tendency to increase calorie intake, but there were considerable variations and these were not significant (Fig. 1D). WT mice treated with the higher doses of corticosterone (10 and $20 \mathrm{mg}$ ) had significantly higher glucose levels and became diabetic (Fig. 1E). WT mice treated with low-dose corticosterone (5 mg) showed increased visceral (perirenal+epididymal; $P=0.0053$ vs WT control; Fig. $1 \mathrm{~F}$ ) and subcutaneous (inguinal; $P=0.0095$ vs WT control; Fig. $1 \mathrm{G}$ ) fat pad weight.

Since mice treated with the $5 \mathrm{mg}$ corticosteronecontaining pellet showed the characteristic metabolic changes of Cushing's syndrome, this pellet was used in further experiments using CB1-KO mice. Glucocorticoidtreated (5 mg) CB1-KO mice showed no increase in calorie
(F) Effect of glucocorticoid treatment on visceral (perirenal + epididymal) fat pad weight in WT mice. (G) Effect of glucocorticoid treatment on subcutaneous (inguinal) fat pad weight in WT mice. Data shown as means \pm s.E.M.S, ${ }^{*} P<0.01$ vs control group. $* P<0.05, * * P<0.01$ and $* * * P<0.001$ vs control group.

intake ( $P=0.4724$ vs $\mathrm{CB} 1-\mathrm{KO}$ control) and a trend to reduced body weight ( $P=0.0514$ vs CB1-KO control).

\section{Hypothalamus}

WT mice treated with a s.c. pellet containing $5 \mathrm{mg}$ corticosterone showed significantly increased AMPK activity in the hypothalamus compared with WT mice treated with the cholesterol pellet ( $P=0.0008$ vs WT Chol; Fig. 2). In CB1-KO mice, this effect was lost: CB1-KO mice treated with $5 \mathrm{mg}$ corticosterone did not show increased AMPK activity in the hypothalamus $(P=0.6079$ vs CB1-KO Chol; Fig. 2). WT and CB1-KO mice treated with cholesterol (control) did not show any significant difference in hypothalamic AMPK activity $(P=0.3275$; Fig. 2). However, glucocorticoid-treated CB1-KO mice

Published by Bioscientifica Ltd. 


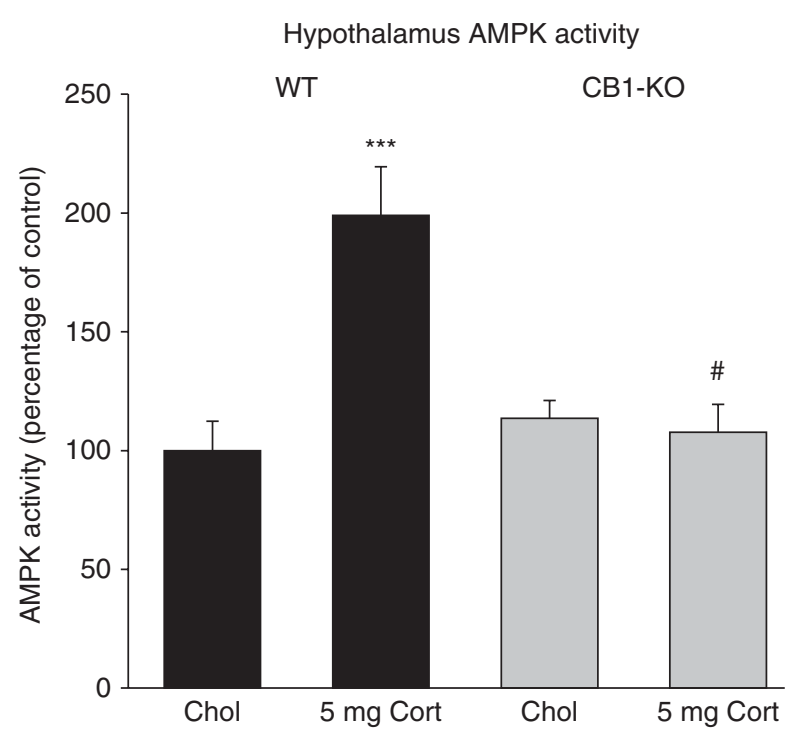

Figure 2

Effect of glucocorticoid treatment on AMPK activity in the hypothalamus of WT and CB1-KO mice. Mice were treated with a s.c. pellet containing either cholesterol (Chol; control) or $5 \mathrm{mg}$ corticosterone (Cort). $* * * P<0.001$ vs equivalent-genotype group and ${ }^{\#} P<0.05$ vs dose-equivalent WT group.

showed lower hypothalamic AMPK activity compared with their WT equivalents $(P=0.0034$; Fig. 2$)$. These results indicate the importance of the $\mathrm{CB} 1$ receptor in the mediation of the stimulatory effect of glucocorticoids on hypothalamic AMPK activity.

\section{Adipose tissues}

WT mice treated with the $5 \mathrm{mg}$ corticosterone pellet showed significantly increased white adipose tissue depot weight ( $P=0.0219$ vs WT Chol). CB1-KO mice showed reduced baseline white adipose tissue depot and glucocorticoid-treated white adipose tissue depot weight when compared with their WT equivalents $(P=0.0185$ vs WT Chol and $P=0.0048$ vs WT 5 mg Cort; Fig. 3A).

Glucocorticoid-treated WT mice showed a significant reduction in visceral fat AMPK activity $(P=0.0006$ vs WT Chol; Fig. 3B). Glucocorticoid-treated CB1-KO mice also showed a significant reduction in visceral fat AMPK activity ( $P=0.0024$ vs CB1-KO Chol; Fig. 3B). Basal and glucocorticoid-treated CB1-KO groups showed significantly increased visceral fat AMPK activity when compared with their WT equivalents (Fig. 3B).

Similarly, glucocorticoid-treated WT mice showed a significant reduction in subcutaneous (inguinal) fat AMPK activity $(P<0.0001$ vs WT Chol; Fig. $3 C)$. Glucocorticoidtreated CB1-KO mice also showed a significant reduction in subcutaneous fat AMPK activity ( $P=0.0013$ vs CB1-KO Chol; Fig. 3C). Basal and glucocorticoid-treated CB1-KO groups showed significantly increased visceral fat AMPK activity when compared with their WT equivalents (Fig. 3C).
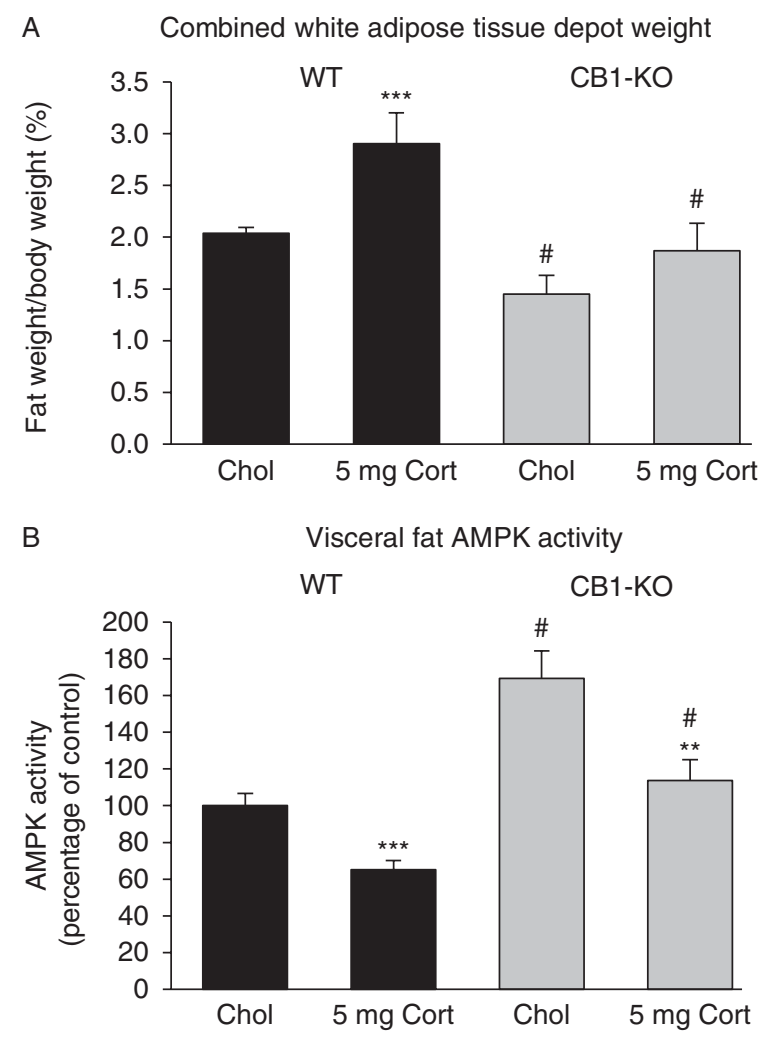

C
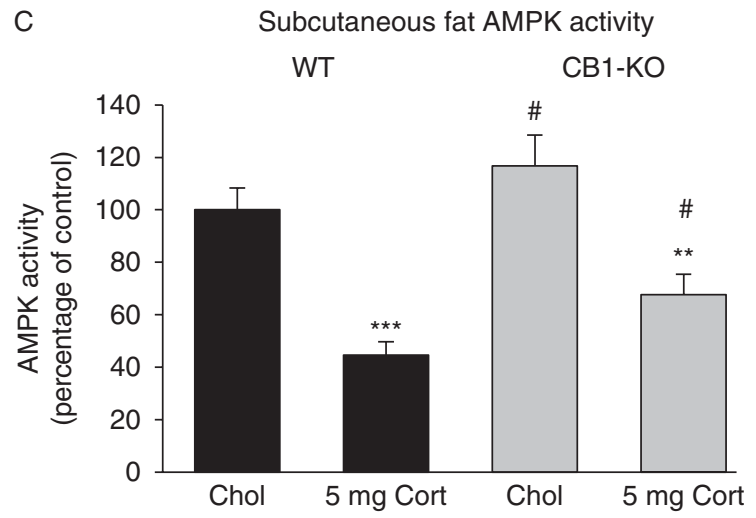

Figure 3

(A) Weight of white adipose tissue depots in WT and CB1-KO mice treated with a s.c. pellet containing either cholesterol (Chol; control) or $5 \mathrm{mg}$ corticosterone (Cort) vs equivalent-genotype group. (B) Effect of glucocorticoid treatment on AMPK activity in visceral (mesenteric + epididymal) fat of WT and CB1-KO mice. Mice were treated with a s.c. pellet containing either cholesterol or $5 \mathrm{mg}$ corticosterone. (C) Effect of glucocorticoid treatment on AMPK activity in subcutaneous (inguinal) fat of WT and CB1-KO mice. Mice were treated with a s.c. pellet containing either cholesterol or $5 \mathrm{mg}$ corticosterone. ${ }^{* * P} P<0.01, * * * P<0.001$ vs equivalentgenotype group and ${ }^{\#} P<0.05$ vs dose-equivalent WT group. 
Liver AMPK activity

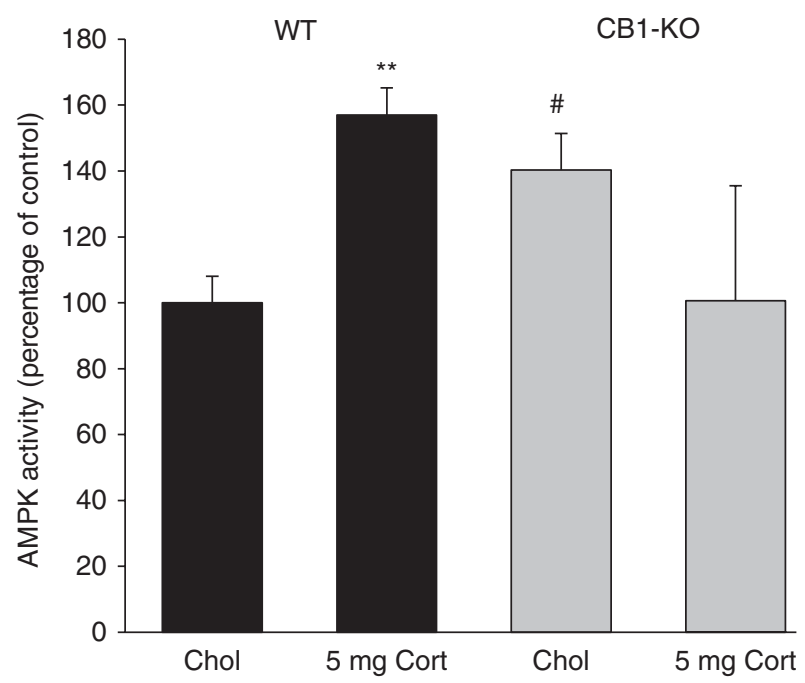

Figure 4

Effect of glucocorticoid treatment on AMPK activity in the liver of WT and CB1-KO mice. Mice were treated with a s.c. pellet containing either cholesterol (Chol; control) or $5 \mathrm{mg}$ corticosterone (Cort). $* * P<0.01$ vs equivalent-genotype group and ${ }^{\#} P<0.05$ vs dose-equivalent WT group.

\section{Liver}

WT mice treated with $5 \mathrm{mg}$ corticosterone showed a significant increase in hepatic AMPK activity $(P=0.004$ vs WT Chol; Fig. 4), similar to our rat model (Christ-Crain et al. 2008). CB1-KO mice showed significantly higher baseline liver AMPK activity when compared with their WT littermates $(P=0.0356)$. However, there was no increase in hepatic AMPK activity after glucocorticoid treatment in CB1-KO mice (Fig. 4).

\section{Heart}

Glucocorticoid-treated WT mice showed a significant reduction in cardiac AMPK activity $(P=0.016$ vs WT control; Fig. 5A). CB1-KO mice showed significantly reduced baseline cardiac AMPK activity when compared with their WT equivalents $(P=0.0056$; Fig. $5 \mathrm{~A})$, and in contrast to WT mice, this reduced AMPK activity was significantly increased by glucocorticoid treatment $(P=0.0075$ vs $\mathrm{CB} 1-\mathrm{KO}$ control).

\section{Discussion}

We have suggested previously that many of the detrimental effects of Cushing's syndrome are mediated, at least partially, by glucocorticoid-induced changes in
AMPK activity in both humans and rats (Christ-Crain et al. 2008, Kola et al. 2008). In the present study, we showed that some of the detrimental effects of glucocorticoids are mediated by the endocannabinoid system.

Hypothalamic AMPK has been shown to play a vital role in the regulation of food intake (Minokoshi et al. 2004, Dzamko et al. 2010) and to be influenced by appetiteregulatory hormones such as leptin, ghrelin and cannabinoids (Andersson et al. 2004, Minokoshi et al. 2004, Kola et al. 2005). In this study, glucocorticoidtreated WT mice displayed significantly increased hypothalamic AMPK activity. Glucocorticoids stimulate hypothalamic AMPK, and data indicate that AMPK may mediate the orexigenic effect of glucocorticoids. Glucocorticoids have been shown to up-regulate the gene expression of orexigenic peptides (neuropeptide $\mathrm{Y}$ and agouti-related peptide) in rat arcuate nucleus via AMPK (Shimizu et al. 2008). Glucocorticoids can also stimulate endocannabinoids in the hypothalamus, as shown in hypothalamic cells in vitro (Di et al. 2003, 2005) and by increasing endocannabinoid content in vivo (Christ-Crain et al. 2008). Hypothalamic endocannabinoid levels have been shown to increase with fasting and to decrease after re-feeding (Kirkham et al. 2002) and to be involved in the mediation of the anorectic effect of leptin (Di Marzo et al. 2001) and of the orexigenic effect of ghrelin (Kola \&

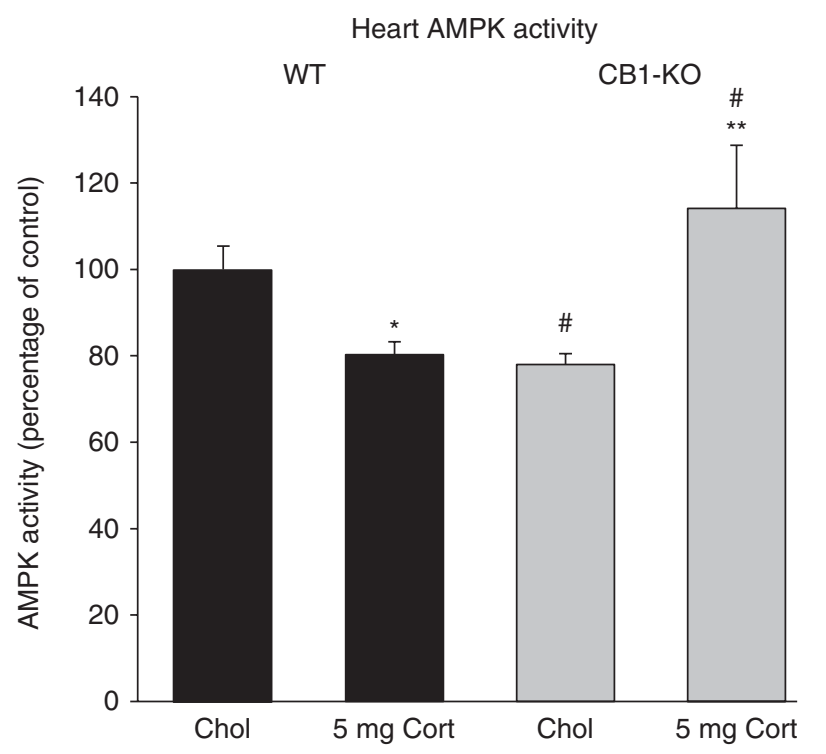

Figure 5

Effect of glucocorticoid treatment on AMPK activity in the heart of WT and CB1-KO mice. Mice were treated with a s.C. pellet containing either cholesterol (Chol; control) or $5 \mathrm{mg}$ corticosterone (Cort). ${ }^{\star} P<0.05$ vs control group with an equivalent genotype, ${ }^{*} P<0.01$ vs equivalentgenotype group and ${ }^{\#} P<0.05$ vs dose-equivalent WT group. 
Korbonits 2009). In this study, we showed that CB1-KO mice are protected from the glucocorticoid-induced increase in hypothalamic AMPK activity.

In humans, the response to glucocorticoids is usually weight gain, but rapid development of high glucocorticoid levels, such as in ectopic ACTH-secreting neuroendocrine tumours, can result in significant catabolism and lack of weight gain. Reduction in weight gain is more often observed in rodents in response to glucocorticoids. In order to achieve the metabolic condition resembling human Cushing's syndrome, glucocorticoid administration in the rodent Cushing's syndrome model, originally set up by Dallman's group, needs to be accompanied by high-dose carbohydrate intake (sucrose drink; Bell et al. 2000). This pronounced catabolic effect of glucocorticoids in rodent models is represented by the decreasing body and fat pad weight with increasing doses of glucocorticoid treatment, where the severe diabetes also contributes to the weight loss. Interestingly, a recent study has described a unique novel mechanism of human, but not rodent, visceral fat accumulation, and this could explain the difference in glucocorticoid sensitivity (Lindroos et al. 2013).

Hypercortisolaemia is associated with increased adipose tissue depots in patients (Rockall et al. 2003a, Geer et al. 2010). Treatment of both WT and CB1-KO mice with corticosterone resulted in a significant reduction of adipose tissue AMPK activity, indicating that the CB1 receptor does not mediate the inhibitory effect of glucocorticoids on adipose tissue AMPK activity. However, it is interesting to note that baseline AMPK activity in the adipose tissues of CB1-KO mice is significantly higher than that in the adipose tissues of WT mice, highlighting the role of the CB1 receptor in the reduction of adipose tissue AMPK activity. Our AMPK assay results are concordant with the results obtained for fat depot weight. Corticosterone treatment is associated with decreased adipose tissue AMPK activity and increased adipose tissue weight. The interesting difference between the two genotypes is that CB1-KO mice show higher adipose tissue AMPK activity and lower adipose tissue weight.

Many of the lipid-accumulating effects of cannabinoids can be explained by their inhibitory effect on adipose tissue AMPK activity (Kola et al. 2005). Chronic blockade of CB1 receptors of SV40 immortalised murine white adipocytes with rimonabant results in significantly increased phosphorylation and activation of AMPK (Perwitz et al. 2010) and blockade of the CB1 receptor leads to a significant reduction of white adipose tissue weight (Jbilo et al. 2005). CB1 antagonism in diet-induced obese mice is associated with the normalisation of adipocyte metabolism (Jourdan et al. 2010). In this study, we showed that CB1-KO mice have significantly higher adipose tissue AMPK activity and significantly lower adipose tissue weight when compared with their WT equivalents. However, CB1-KO mice are not protected from the inhibitory effects of glucocorticoids on adipose tissue AMPK activity. Thus, in this study, we showed that the CB1 receptor does not mediate the inhibitory effect of glucocorticoids on adipose tissue AMPK activity.

Cushing's syndrome is associated with increased hepatic fat accumulation (Rockall et al. 2003b); therefore, reduced hepatic AMPK activity could be expected in glucocorticoid-treated animals. However, in both rat and mouse studies, increased hepatic AMPK has been observed (Viana et al. 2006, Christ-Crain et al. 2008). Although the activation of AMPK suppresses nuclear accumulation of the lipogenic transcription factor SREBP-1C (SREBF1), resulting in reduced transcription of its target genes, acetyl-CoA carboxylase (Acc (Acaca)) and fatty acid synthase (Fas (Fasn)), and inhibition of aberrant lipogenesis in the liver (Li et al. 2011), it is important to note that liver metabolism is complex in high glucocorticoid states. The direct effect of glucocorticoids is combined with the effect of high glucose and high insulin levels, as well as increased net flux of fatty acids into the liver (Foretz et al. 2005), leading to enhanced hepatic lipid oxidation. While glycolysis is stimulated by glucocorticoids, insulin and AMPK, gluconeogenesis is stimulated by glucocorticoids, but inhibited by insulin and AMPK. Therefore, increased glucocorticoid and insulin levels together with increased lipid influx may ultimately lead to increased AMPK activity in hepatic tissues.

Peripheral lipogenesis occurs in the liver independent of food intake, and endocannabinoids act via the hepatic CB1 receptors to induce hepatic steatosis (Tam et al. 2011). A reversal of this effect has been observed with CB1 receptor antagonism (Gary-Bobo et al. 2007). The activation of the CB1 receptor in mice increases the gene expression of Srebp-1c and results in increased de novo fatty acid synthesis in the liver (Osei-Hyiaman et al. 2005). Cannabinoids may stimulate hepatic lipogenesis through the inhibition of AMPK (Kola et al. 2005). Interestingly, increased baseline hepatic AMPK activity in CB1-KO mice when compared with their WT littermates may be a reflection of the loss of endocannabinoid/CB1-driven hepatic lipogenesis.

CB1-KO mice failed to show an increase in hepatic AMPK activity after glucocorticoid treatment. This might suggest that the CB1 receptor is involved in the AMPK-stimulatory effect of glucocorticoids in the liver.

Published by Bioscientifica Ltd. 
Alternatively, the reduced adipose tissue stores present in CB1-KO mice might produce less fatty acid influx and stimulation of the liver compared with their WT littermates. It is also possible that the effects of glucocorticoids on the liver are partly mediated through the hypothalamus-vagus circuit, as it is known that central endocannabinoids regulate glucose production in the liver (O'Hare et al. 2011).

There is evidence that glucocorticoids can interact directly with myocardial cells to alter their structure and function (Hadoke et al. 2009). Acute glucocorticoid treatment results in the stimulation of cardiac AMPK (Qi et al. 2006, Puthanveetil et al. 2008). However, with chronic glucocorticoid treatment, we have found reduced cardiac AMPK activity in both rats (Christ-Crain et al. 2008) and mice. AMPK is inhibited by glycogen (McBride et al. 2009); therefore, reduced cardiac AMPK activity may occur in glucocorticoid-treated animals as a result of the increased cardiac glycogen content. AMPK has cardioprotective effects, and reduction of its activity may directly explain the cardiac abnormalities observed in chronic glucocorticoid excess. Long-term inhibition of AMPK has detrimental cardiac consequences. It has been shown that AMPK mediates ischaemic glucose uptake and glycolysis, protects cardiac ATP levels, and limits post-ischaemic cardiac dysfunction (Russell et al. 2004).

Cannabinoids stimulate cardiac AMPK activity (Kola et al. 2005), and this may mediate their cardioprotective effects (Hiley \& Ford 2004). In this study, we showed that CB1-KO mice display significantly reduced baseline cardiac AMPK activity when compared with their WT equivalents. This confirms the stimulatory effect of the cannabinoidCB1 system on cardiac AMPK activity. Similar to glucocorticoid treatment, loss of the $\mathrm{CB} 1$ receptor leads to a reduction of cardiac AMPK activity and potentially a detrimental effect on the heart.

It is possible that glucocorticoids have a dual effect on cardiac AMPK activity; there may be a CB1-dependent inhibitory effect and a CB1-independent stimulatory effect. Endocannabinoids have been shown to stimulate cardiac AMPK activity (Kola et al. 2005); therefore, the CB1-dependent inhibitory effect of glucocorticoids on cardiac AMPK activity may result from the inhibition of cardiac endocannabinoid synthesis. One possible explanation for the CB1-independent stimulatory effect of glucocorticoids on cardiac AMPK is the inhibitory effect of glucocorticoids on noradrenaline reuptake in the heart (Grundemann et al. 1998). If noradrenaline reuptake is inhibited, the increased level of noradrenaline can stimulate AMPK activity (Xu et al. 2007). In the WT animals, the CB1-dependent effect is stronger, and this could explain why we observed an inhibition of AMPK activity, while in the CB1-KO mice, we observed only the stimulatory effect.

It is currently unclear how glucocorticoids lead to the activation of the cannabinoid pathway. Di et al. (2003, 2005) have elegantly demonstrated this effect using in vitro studies and have reported a possible membrane receptor-mediated mechanism. More recent studies have confirmed these findings (Wang et al. 2012). Clearly, this aspect requires further studies to elucidate the exact mechanisms involved in glucocorticoid-induced endocannabinoid activation.

In conclusion, our data suggest that an intact cannabinoid pathway is required for the hypothalamic AMPK effects of glucocorticoids, while the adipose tissue changes may occur independent of the CB1 receptor. In addition, knockout of the $C b 1$ receptor appears to alter the responsiveness of the liver and myocardial tissues to glucocorticoids. These data indicate the importance of the CB1 receptor in the effects of glucocorticoids on various tissues and interaction between glucocorticoids and the novel peripheral CB1 antagonist molecules should be explored.

\section{Declaration of interest}

The authors declare that there is no conflict of interest that could be perceived as prejudicing the impartiality of the research reported.

\section{Funding}

This study was supported by sponsorship from the Goldberg-Schachmann \& Freda Becker Trusts and Rod Flower Summer Vacation Scholarship (Barts and the London School of Medicine and Dentistry; M S), NIHR Clinical Fellowship (J D T), the Seventh EU Research Framework Program (HealthF2-2010-259772), the Lendület Award of the Hungarian Academy of Sciences (C F and T F) and the Wellcome Trust Project Grant (B K and M K).

\section{References}

Andersson U, Filipsson K, Abbott CR, Woods A, Smith K, Bloom SR, Carling D \& Small CJ 2004 AMP-activated protein kinase plays a role in the control of food intake. Journal of Biological Chemistry 279 12005-12008. (doi:10.1074/jbc.C300557200)

Bell ME, Bhatnagar S, Liang J, Soriano L, Nagy TR \& Dallman MF 2000 Voluntary sucrose ingestion, like corticosterone replacement, prevents the metabolic deficits of adrenalectomy. Journal of Neuroendocrinology 12 461-470. (doi:10.1046/j.1365-2826.2000.00488.x)

Boyle JG, Logan PJ, Jones GC, Small M, Sattar N, Connell JM, Cleland SJ \& Salt IP 2011 AMP-activated protein kinase is activated in adipose tissue of individuals with type 2 diabetes treated with metformin: a randomised glycaemia-controlled crossover study. Diabetologia 54 1799-1809. (doi:10.1007/s00125-011-2126-4)

Butler H \& Korbonits M 2009 Cannabinoids for clinicians: the rise and fall of the cannabinoid antagonists. European Journal of Endocrinology 161 655-662. (doi:10.1530/EJE-09-0511) http://joe.endocrinology-journals.org DOI: 10.1530/JOE-13-0192
(C) 2013 Society for Endocrinology Printed in Great Britain 
Christ-Crain M, Kola B, Lolli F, Fekete C, Seboek D, Wittmann G, Feltrin D, Igreja SC, Ajodha S, Harvey-White J et al. 2008 AMP-activated protein kinase mediates glucocorticoid-induced metabolic changes: a novel mechanism in Cushing's syndrome. FASEB Journal 22 1672-1683. (doi:10.1096/fj.07-094144)

Cota D, Marsicano G, Tschop M, Grubler Y, Flachskamm C, Schubert M, Auer D, Yassouridis A, Thone-Reineke C, Ortmann S et al. 2003 The endogenous cannabinoid system affects energy balance via central orexigenic drive and peripheral lipogenesis. Journal of Clinical Investigation 112 423-431. (doi:10.1172/JCI17725)

Dallman MF, Pecoraro N, Akana SF, la Fleur SE, Gomez F, Houshyar H, Bell ME, Bhatnagar S, Laugero KD \& Manalo S 2003 Chronic stress and obesity: a new view of "comfort food". PNAS 100 11696-11701. (doi:10.1073/pnas.1934666100)

Di S, Malcher-Lopes R, Halmos KC \& Tasker JG 2003 Nongenomic glucocorticoid inhibition via endocannabinoid release in the hypothalamus: a fast feedback mechanism. Journal of Neuroscience $\mathbf{2 3}$ 4850-4857.

Di S, Malcher-Lopes R, Marcheselli VL, Bazan NG \& Tasker JG 2005 Rapid glucocorticoid-mediated endocannabinoid release and opposing regulation of glutamate and $\gamma$-aminobutyric acid inputs to hypothalamic magnocellular neurons. Endocrinology 146 4292-4301. (doi:10.1210/en.2005-0610)

Di Marzo V, Goparaju SK, Wang L, Liu J, Batkai S, Jarai Z, Fezza F, Miura GI, Palmiter RD \& Sugiura T 2001 Leptin-regulated endocannabinoids are involved in maintaining food intake. Nature $\mathbf{4 1 0} 822-825$. (doi:10.1038/35071088)

Dzamko N, van Denderen BJ, Hevener AL, Jorgensen SB, Honeyman J, Galic S, Chen ZP, Watt MJ, Campbell DJ, Steinberg GR et al. 2010 AMPK $\beta 1$ deletion reduces appetite, preventing obesity and hepatic insulin resistance. Journal of Biological Chemistry 285 115-122. (doi:10.1074/jbc.M109.056762)

Foretz M, Ancellin N, Andreelli F, Saintillan Y, Grondin P, Kahn A, Thorens B, Vaulont S \& Viollet B 2005 Short-term overexpression of a constitutively active form of AMP-activated protein kinase in the liver leads to mild hypoglycemia and fatty liver. Diabetes 54 1331-1339. (doi:10.2337/diabetes.54.5.1331)

Gary-Bobo M, Elachouri G, Gallas JF, Janiak P, Marini P, Ravinet-Trillou C, Chabbert M, Cruccioli N, Pfersdorff C, Roque C et al. 2007 Rimonabant reduces obesity-associated hepatic steatosis and features of metabolic syndrome in obese Zucker fa/fa rats. Hepatology 46 122-129. (doi:10.1002/hep.21641)

Gauthier MS, O’Brien EL, Bigornia S, Mott M, Cacicedo JM, Xu XJ, Gokce N, Apovian C \& Ruderman N 2011 Decreased AMP-activated protein kinase activity is associated with increased inflammation in visceral adipose tissue and with whole-body insulin resistance in morbidly obese humans. Biochemical and Biophysical Research Communications 404 382-387. (doi:10.1016/j.bbrc.2010.11.127)

Geer EB, Shen W, Gallagher D, Punyanitya M, Looker HC, Post KD \& Freda PU 2010 MRI assessment of lean and adipose tissue distribution in female patients with Cushing's disease. Clinical Endocrinology $\mathbf{7 3}$ 469-475. (doi:10.1111/j.1365-2265.2010.03829.x)

Grundemann D, Schechinger B, Rappold GA \& Schomig E 1998 Molecular identification of the corticosterone-sensitive extraneuronal catecholamine transporter. Nature Neuroscience 1 349-351. (doi:10.1038/1557)

Hadoke PW, Iqbal J \& Walker BR 2009 Therapeutic manipulation of glucocorticoid metabolism in cardiovascular disease. British Journal of Pharmacology 156 689-712. (doi:10.1111/j.1476-5381.2008.00047.x)

Hawley SA, Boudeau J, Reid JL, Mustard KJ, Udd L, Makela TP, Alessi DR \& Hardie DG 2003 Complexes between the LKB1 tumor suppressor, STRAD $\alpha / \beta$ and MO25 $\alpha / \beta$ are upstream kinases in the AMP-activated protein kinase cascade. Journal of Biology 2 28. (doi:10.1186/ 1475-4924-2-28)

Hiley CR 2009 Endocannabinoids and the heart. Journal of Cardiovascular Pharmacology 53 267-276. (doi:10.1097/FJC.0b013e318192671d)

http://joe.endocrinology-journals.org DOI: $10.1530 /$ JOE-13-0192
() 2013 Society for Endocrinology Printed in Great Britain
Hiley CR \& Ford WR 2004 Cannabinoid pharmacology in the cardiovascular system: potential protective mechanisms through lipid signalling. Biological Reviews of the Cambridge Philosophical Society 79 187-205. (doi:10.1017/S1464793103006201)

Jbilo O, Ravinet-Trillou C, Arnone M, Buisson I, Bribes E, Peleraux A, Penarier G, Soubrie P, Le Fur G, Galiegue S et al. 2005 The CB1 receptor antagonist rimonabant reverses the diet-induced obesity phenotype through the regulation of lipolysis and energy balance. FASEB Journal 19 1567-1569. (doi:10.1096/fj.04-3177fje)

Jourdan T, Djaouti L, Demizieux L, Gresti J, Verges B \& Degrace P 2010 CB1 antagonism exerts specific molecular effects on visceral and subcutaneous fat and reverses liver steatosis in diet-induced obese mice. Diabetes 59 926-934. (doi:10.2337/db09-1482)

Kahn BB, Alquier T, Carling D \& Hardie DG 2005 AMP-activated protein kinase: ancient energy gauge provides clues to modern understanding of metabolism. Cell Metabolism 1 15-25. (doi:10.1016/j.cmet.2004.12.003)

Kirkham TC, Williams CM, Fezza F \& Di Marzo V 2002 Endocannabinoid levels in rat limbic forebrain and hypothalamus in relation to fasting, feeding and satiation: stimulation of eating by 2-arachidonoyl glycerol. British Journal of Pharmacology 136 550-557. (doi:10.1038/sj. bjp.0704767)

Kola B \& Korbonits M 2009 Shedding light on the intricate puzzle of ghrelin's effects on appetite regulation. Journal of Endocrinology 202 191-198. (doi:10.1677/JOE-09-0056)

Kola B, Hubina E, Tucci SA, Kirkham TC, Garcia EA, Mitchell SE, Williams LM, Hawley SA, Hardie DG, Grossman AB et al. 2005 Cannabinoids and ghrelin have both central and peripheral metabolic and cardiac effects via AMP-activated protein kinase. Journal of Biological Chemistry $\mathbf{2 8 0}$ 25196-25201. (doi:10.1074/jbc.C500175200)

Kola B, Boscaro M, Rutter GA, Grossman AB \& Korbonits M 2006 Expanding role of AMPK in endocrinology. Trends in Endocrinology and Metabolism 17 205-215. (doi:10.1016/j.tem.2006.05.006)

Kola B, Christ-Crain M, Lolli F, Arnaldi G, Giacchetti G, Boscaro M, Grossman AB \& Korbonits M 2008 Changes in adenosine 5 -monophosphate-activated protein kinase as a mechanism of visceral obesity in Cushing's syndrome. Journal of Clinical Endocrinology and Metabolism 93 4969-4973. (doi:10.1210/jc.2008-1297)

Ledent C, Valverde O, Cossu G, Petitet F, Aubert JF, Beslot F, Bohme GA, Imperato A, Pedrazzini T, Roques BP et al. 1999 Unresponsiveness to cannabinoids and reduced addictive effects of opiates in CB1 receptor knockout mice. Science 283 401-404. (doi:10.1126/science.283.5400.401)

Li Y, Xu S, Mihaylova MM, Zheng B, Hou X, Jiang B, Park O, Luo Z, Lefai E, Shyy JY et al. 2011 AMPK phosphorylates and inhibits SREBP activity to attenuate hepatic steatosis and atherosclerosis in diet-induced insulin-resistant mice. Cell Metabolism 13 376-388. (doi:10.1016/ j.cmet.2011.03.009)

Lindroos J, Husa J, Mitterer G, Haschemi A, Rauscher S, Haas R, Groger M, Loewe R, Kohrgruber N, Schrogendorfer KF et al. 2013 Human but not mouse adipogenesis is critically dependent on LMO3. Cell Metabolism 18 62-74. (doi:10.1016/j.cmet.2013.05.020)

McBride A, Ghilagaber S, Nikolaev A \& Hardie DG 2009 The glycogen-binding domain on the AMPK $\beta$ subunit allows the kinase to act as a glycogen sensor. Cell Metabolism 9 23-34. (doi:10.1016/j.cmet.2008.11.008)

Minokoshi Y, Alquier T, Furukawa N, Kim YB, Lee A, Xue B, Mu J, Foufelle F, Ferre P, Birnbaum MJ et al. 2004 AMP-kinase regulates food intake by responding to hormonal and nutrient signals in the hypothalamus. Nature 428 569-574. (doi:10.1038/nature02440)

Muiesan ML, Lupia M, Salvetti M, Grigoletto C, Sonino N, Boscaro M, Rosei EA, Mantero F \& Fallo F 2003 Left ventricular structural and functional characteristics in Cushing's syndrome. Journal of the American College of Cardiology 41 2275-2279. (doi:10.1016/S0735-1097(03)00493-5)

O'Hare JD, Zielinski E, Cheng B, Scherer T \& Buettner C 2011 Central endocannabinoid signaling regulates hepatic glucose production and systemic lipolysis. Diabetes 60 1055-1062. (doi:10.2337/db10-0962)

Osei-Hyiaman D, Depetrillo M, Pacher P, Liu J, Radaeva S, Batkai S, HarveyWhite J, Mackie K, Offertaler L, Wang L et al. 2005 Endocannabinoid 
activation at hepatic CB1 receptors stimulates fatty acid synthesis and contributes to diet-induced obesity. Journal of Clinical Investigation 115 1298-1305. (doi:10.1172/JCI23057)

Osei-Hyiaman D, Liu J, Zhou L, Godlewski G, Harvey-White J, Jeong WI, Batkai S, Marsicano G, Lutz B, Buettner C et al. 2008 Hepatic CB1 receptor is required for development of diet-induced steatosis, dyslipidemia, and insulin and leptin resistance in mice. Journal of Clinical Investigation 118 3160-3169. (doi:10.1172/JCI34827)

Perwitz N, Wenzel J, Wagner I, Buning J, Drenckhan M, Zarse K, Ristow M, Lilienthal W, Lehnert H \& Klein J 2010 Cannabinoid type 1 receptor blockade induces transdifferentiation towards a brown fat phenotype in white adipocytes. Diabetes, Obesity \& Metabolism 12 158-166. (doi:10.1111/j.1463-1326.2009.01133.x)

Pivonello R, Faggiano A, Lombardi G \& Colao A 2005 The metabolic syndrome and cardiovascular risk in Cushing's syndrome. Endocrinology and Metabolism Clinics of North America 34 327-339, viii. (doi:10.1016/ j.ecl.2005.01.010)

Puthanveetil P, Wang F, Kewalramani G, Kim MS, Hosseini-Beheshti E, Ng N, Lau W, Pulinilkunnil T, Allard M, Abrahani A et al. 2008 Cardiac glycogen accumulation after dexamethasone is regulated by AMPK. American Journal of Physiology. Heart and Circulatory Physiology 295 H1753-H1762. (doi:10.1152/ajpheart.518.2008)

Qi D, An D, Kewalramani G, Qi Y, Pulinilkunnil T, Abrahani A, Al-Atar U, Ghosh S, Wambolt RB, Allard MF et al. 2006 Altered cardiac fatty acid composition and utilization following dexamethasone-induced insulin resistance. American Journal of Physiology. Endocrinology and Metabolism 291 E420-E427. (doi:10.1152/ajpendo.00083.2006)

Rockall AG, Sohaib SA, Evans D, Kaltsas G, Isidori AM, Monson JP, Besser GM, Grossman AB \& Reznek RH 2003a Computed tomography assessment of fat distribution in male and female patients with Cushing's syndrome. European Journal of Endocrinology 149 561-567. (doi:10.1530/eje.0.1490561)

Rockall AG, Sohaib SA, Evans D, Kaltsas G, Isidori AM, Monson JP, Besser GM, Grossman AB \& Reznek RH 2003b Hepatic steatosis in Cushing's syndrome: a radiological assessment using computed tomography. European Journal of Endocrinology 149 543-548. (doi:10.1530/eje.0.1490543)

Russell RR III, Li J, Coven DL, Pypaert M, Zechner C, Palmeri M, Giordano FJ, Mu J, Birnbaum MJ \& Young LH 2004 AMP-activated protein kinase mediates ischemic glucose uptake and prevents postischemic cardiac dysfunction, apoptosis, and injury. Journal of Clinical Investigation 114 495-503. (doi:10.1172/JCI19297)
Shimizu H, Arima H, Watanabe M, Goto M, Banno R, Sato I, Ozaki N, Nagasaki H \& Oiso Y 2008 Glucocorticoids increase neuropeptide $\mathrm{Y}$ and agouti-related peptide gene expression via adenosine monophosphate-activated protein kinase signaling in the arcuate nucleus of rats. Endocrinology 149 4544-4553. (doi:10.1210/ en.2008-0229)

van Staa TP, Leufkens HG, Abenhaim L, Begaud B, Zhang B \& Cooper C 2000 Use of oral corticosteroids in the United Kingdom. QJM 93 105-111. (doi:10.1093/qjmed/93.2.105)

Tam J, Liu J, Mukhopadhyay B, Cinar R, Godlewski G \& Kunos G 2011 Endocannabinoids in liver disease. Hepatology 53 346-355. (doi:10.1002/hep.24077)

Turu G, Varnai P, Gyombolai P, Szidonya L, Offertaler L, Bagdy G, Kunos G \& Hunyady L 2009 Paracrine transactivation of the CB1 cannabinoid receptor by AT1 angiotensin and other Gq/11 protein-coupled receptors. Journal of Biological Chemistry 284 16914-16921. (doi:10.1074/jbc.M109.003681)

Underdown NJ, Hiley CR \& Ford WR 2005 Anandamide reduces infarct size in rat isolated hearts subjected to ischaemia-reperfusion by a novel cannabinoid mechanism. British Journal of Pharmacology 146 809-816. (doi:10.1038/sj.bjp.0706391)

Viana AY, Sakoda H, Anai M, Fujishiro M, Ono H, Kushiyama A, Fukushima Y, Sato Y, Oshida Y, Uchijima Y et al. 2006 Role of hepatic AMPK activation in glucose metabolism and dexamethasone-induced regulation of AMPK expression. Diabetes Research and Clinical Practice 73 135-142. (doi:10.1016/j.diabres.2005.12.011)

Wang M, Hill MN, Zhang L, Gorzalka BB, Hillard CJ \& Alger BE 2012 Acute restraint stress enhances hippocampal endocannabinoid function via glucocorticoid receptor activation. Journal of Psychopharmacology 26 56-70. (doi:10.1177/0269881111409606)

Wittmann G, Deli L, Kallo I, Hrabovszky E, Watanabe M, Liposits Z \& Fekete C 2007 Distribution of type 1 cannabinoid receptor (CB1)immunoreactive axons in the mouse hypothalamus. Journal of Comparative Neurology 503 270-279. (doi:10.1002/cne.21383)

Xu M, Zhao YT, Song Y, Hao TP, Lu ZZ, Han QD, Wang SQ \& Zhang YY 2007 $\alpha 1$-Adrenergic receptors activate AMP-activated protein kinase in rat hearts. Sheng Li Xue Bao 59 175-182.

Zelena D, Barna I, Pinter O, Klausz B, Varga J \& Makara GB 2011 Congenital absence of vasopressin and age-dependent changes in ACTH and corticosterone stress responses in rats. Stress 14 420-430. (doi:10.3109/ 10253890.2011.552991)

Received in final form 21 July 2013

Accepted 24 July 2013

Accepted Preprint published online 24 July 2013
(ㄷ) 2013 Society for Endocrinology Printed in Great Britain 